\title{
Evaluation of the cytotoxicity and phototoxicity of Caryocar brasiliense supercritical carbon dioxide extract
}

\author{
Lilian FB Amaral $^{1 *}$, Patricia Moriel ${ }^{1}$, Mary Ann Foglio ${ }^{2}$ and Priscila G Mazzola ${ }^{1}$
}

\begin{abstract}
Background: Caryocar brasiliense Camb (Pequi) is a typical Brazilian Cerrado fruit tree. Its fruit is used as a vitamin source for culinary purposes and as a source of oil for the manufacture of cosmetics. C. brasiliense supercritical $\mathrm{CO}_{2}$ extracts exhibit antimicrobial activity against the bacteria Escherichia coli, Pseudomonas aeruginosa, and Staphylococcus aureus and also possess antioxidant activity. This study was designed to evaluate the in vitro cytotoxicity and phototoxicity of the supercritical $\mathrm{CO}_{2}$ extract obtained from the leaves of this species.
\end{abstract}

Methods: In vitro cytotoxicity and phototoxicity of $\mathrm{C}$. brasiliense supercritical $\mathrm{CO}_{2}$ extracts were assessed using a tetrazolium-based colorimetric assay (XTT) and Neutral Red methods.

Results: We found that the C. brasiliense (Pequi) extract obtained by supercritical $\mathrm{CO}_{2}$ extraction did not present cytotoxic and phototoxic hazards.

Conclusions: This finding suggests that the extract may be useful for the development of cosmetic and/or pharmaceutical products.

Keywords: Pequi, Supercritical $\mathrm{CO}_{2}$ extraction, Cytotoxicity, Phototoxicity

\section{Background}

Medicinal plants have been the subject of intense research due to their potential use in cosmetic and pharmaceutical actives and also due to the growing consumer interest in using less "aggressive" products derived from natural sources. There is considerable published data regarding the efficacy of plant extracts, but information on the toxicity of these natural resources is not sufficient [1]. A careful screening of plant extracts for their activities against microorganisms or potential diseases is required to ascertain their toxic potential [2].

During the last decade, in vitro studies of cell and tissue cultures have become important approaches to understand the consequences of exposure and to assign risk. In vitro tests are commonly used for product development, drug discovery, and safety evaluation [3].

\footnotetext{
* Correspondence: liufbarbosa@yahoo.com.br

'Department of Clinical Pathology, Faculty of Medical Sciences, University of Campinas (FCM-UNICAMP), Rua Tessália Vieira de Camargo, 126 Campinas, SP, Brasil

Full list of author information is available at the end of the article
}

In vitro cytotoxicity and phototoxicity methods have been evaluated as means to reduce and refine the use of animals in testing procedures. These methods may be helpful for predicting acute toxicity in vivo [4].

Cytotoxicity has been defined as the adverse effects resulting from interference with the structures and/or processes essential for the survival, proliferation, and/or function of cells [5]. Grisham and Smith [6] also concluded that in vitro cytotoxicity assays may be useful for the prediction of acute lethal potency since the actions of substances that produce injury and death are exerted ultimately at the cellular level.

Phototoxicity is an acute reaction that can be induced by single treatment with a chemical and ultraviolet (UV) or visible radiation. Photoirritation is used to describe phototoxic reactions in the skin due to topically-applied substances combined with light exposure [7].

Caryocar brasiliense Camb (Pequi) is a typical Brazilian Cerrado fruit tree [8]. Its fruit is used as a vitamin source for culinary purposes and as a source of oil for the manufacture of cosmetics [9]. "Pequi" (originates from 
the Tupi-Guarani language) means "spiny-skinned fruit", which refers to a shell covered with thin woody spikes, protecting the seeds [10].

Pequi oil is employed for the treatment of hoarseness, sore throat, bronchitis, and cough. It is used topically for dressing wounds as well as for relieving muscle aches, rheumatic pains, and contusions [11]. It is also used for lung infections and has veterinary indications [12]. It can be employed against respiratory problems and scarring [13]. Pequi oil has anti-inflammatory activity [14] and can be used as an aphrodisiac as well as for the stimulation of bile production [15].

This oil has been reported to contain vitamin A and fatty acids (e.g., palmitic, oleic, myristic, palmitoleic, stearic, linoleic, linolenic acids) [16], which are essential for skin hydration and barrier maintenance, as well as the hydrolipidic mantle [17].

Previously, we demonstrated that supercritical $\mathrm{CO}_{2}$ extracts from the leaves of $C$. brasiliense exhibit antimicrobial activity against Escherichia coli, Pseudomonas aeruginosa, and Staphylococcus aureus. They also possess antioxidant activity when compared with a vitamin-E standard [18]. Information about the toxicological potential of C. brasiliense is very limited and not sufficient to support its safety. Given the substantial potential of this Brazilian species for wide application in clinical and cosmetic areas, we evaluated the in vitro cytotoxicity and phototoxicity of supercritical $\mathrm{CO}_{2}$ extract obtained from the leaves of C. brasiliense.

\section{Methods}

Plant material

In January 2011, approximately $25 \mathrm{~kg}$ of C. brasiliense leaves were collected from Montes Claros (Minas Gerais, Brazil). Leaves were dried in an air-circulating oven at $40^{\circ} \mathrm{C}$ and then ground in a knife mill. They were stored in plastic bags at room temperature to protect them from humidity. Samples of complete leaves, representative of the species, were identified by the Herbarium of the University of Campinas (São Paulo, Brazil), where a voucher was deposited (reference number UEC 150024).

An apolar extract from C. brasiliense was prepared by Chemyunion Química Ltda (São Paulo, Brazil) using a supercritical $\mathrm{CO}_{2}$ extraction system comprising a heated extraction column, $\mathrm{CO}_{2}$ and co-solvent pumps, a thermostatic bath, and a pressure gauge. These activities were conducted with the approval of the Brazilian Institute of Environment and Renewable Natural Resources, which granted access to genetic resources under number 008/2009 (case number 02001.003785/2011-59).

\section{Screening of main chemical classes}

The phytochemical profile of the crude plant extract was screened using a thin-layer chromatography (TLC) system that tested specific fractions generated, based on differing polarity, during extraction. This procedure fractionated the crude extract into fiber, a neutral extract, moderately polar extract, basic extract, and polar extract according to the method described by Harborne [19].

The chemical profile of the extract was analyzed for the presence of alkaloids, saponins, anthraquinones, steroids, tannins, flavonoids, and phenolic compounds according to conventional colorimetric methods. Compounds from different chemical families were detected by precipitation reactions or staining using reagents specific to each family of compounds.

\section{Cell culture}

Murine fibroblasts (3T3) (ATCC ${ }^{\ominus}$ CCL-92 ${ }^{2 \mathrm{~m}}$; American Type Culture Collection, Manassas, VA, USA) were subcultured in Dulbecco's modified Eagle's medium (DMEM; Sigma-Aldrich, Saint Louis, MO, USA) supplemented with $0.10 \%$ gentamycin, $0.80 \%$ Amphotericin B, $0.001 \%$ epidermal growth factor, and $10 \%$ fetal bovine serum (Sigma-Aldrich). Plates were incubated overnight at $37^{\circ} \mathrm{C}$ in a $5 \% \mathrm{CO}_{2}$ incubator. After confluence, cells were trypsinized ( $0.25 \%$ trypsin) for $1 \mathrm{~min}$ and seeded on 96-well culture plates $\left(1 \times 10^{4}\right.$ cells/well $)$ for incubation with a $C$. brasiliense supercritical $\mathrm{CO}_{2}$ extract (CBSE).

\section{Cytotoxicity testing using a tetrazolium-based colorimet- ric assay (XTT)}

Cell viability was determined using the XTT assay (Sigma-Aldrich). This test is based on conversion of the yellow tetrazolium hydroxide (sodium 3'-[1-(phenylaminocarbonyl)-3,4-tetrazolium]-bis [4-methoxy-6-nitro] benzene sulfonic acid hydrate) to an orange formazan color by the mitochondrial enzyme succinate dehydrogenase in metabolically active viable cells.

The culture medium was removed from 96-well plates (Nunc, Roskilde, MD, USA) containing cells subcultured previously at $37^{\circ} \mathrm{C}$ in a $5 \% \mathrm{CO}_{2}$ incubator. CBSE $(0.0001-50.0 \% \mathrm{w} / \mathrm{v})$ well dissolved in culture medium was added to the cells for $48 \mathrm{~h}$ at identical conditions of cell culture. After incubation, contents of the wells were aspirated carefully, and the wells were rinsed thrice with Earle's balanced salt solution (EBSS). XTT (In Cytotox XTT KXT 96.300; Xenometrix AG, Allschwil, Switzerland) was added to the culture, which was incubated at $37^{\circ} \mathrm{C}$ for $4 \mathrm{~h}$. The absorbance of each well was determined at $450 \mathrm{~nm}$ in a microplate reader (Multiscan MS; Labsystems, Helsinki, Finland). The control group comprised untreated wells. Cell death was expressed as a percentage. The half-maximal inhibitory concentration $\left(\mathrm{IC}_{50}\right)$ of CBSE was estimated through analyses of linear interpolation. 
Phototoxicity: the 3 T3 neutral red uptake (NRU) assay

Cells were prepared as described in the cytotoxicity assay using two plates. The 3 T3 NRU test for phototoxicity requires 60-min exposure to sample dilutions in EBSS followed by exposure to UVA light $\left(5 \mathrm{J.cm}^{-2}\right.$; SOL-500 Sun Simulation System; Dr Honle, Planegg, Germany) of one of the plates. The other plate was used as a nonirradiated control. After washing both plates with EBBS, cells were incubated for $24 \mathrm{~h}$ at $37^{\circ} \mathrm{C}$ in a $5 \% \mathrm{CO}_{2}$ incubator. Plates were washed, incubated with Neutral Red (NR) dye (In Cytotox KRCV 96.300; Xenometrix) and re-washed. NR desorb solution was added and NR absorption measured at $540 \mathrm{~nm}$ in a microplate reader (Multiscan MS; Labsystems). Cell viability was calculated for each treatment. Phototoxicity was assessed by comparing the differences in toxicity between negative control plates that had not been exposed to UVA light and test plates exposed to UVA light. Cell death was also expressed as a percentage, and $\mathrm{IC}_{50}$ of the CBSE estimated through analyses of linear interpolation.

The Photo-irritation Factor (PIF) was determined according to the following equation:

$$
P I F=I C 50[-U V] / I C 50[+U V]
$$

Equation 1: Calculation of the Photo-irritation Factor. A second predictor of phototoxicity, the mean photo effect (MPE) was also calculated [20]. The values obtained from PIF and MPE allow categorization as "no photoirritant" (PIF <2 or MPE <0.1), "probable photoirritant" (PIF $>2$ and $<5$ or an MPE $>0.1$ and $<0.15$ ) and "photoirritant" (PIF $>5$ or an MPE $>0.15$ ) [21].

\section{Statistical analyses}

Optical density data (in triplicate) are the mean \pm standard deviation. A parametric method, one-way analysis of variance (ANOVA), followed by the Dunnett's test was used to compare data among all groups. A P value $<0.05$ was considered statistically significant.

\section{Results and discussion}

\section{Screening of the crude extract}

The terpenoid fraction was identified with anisaldehyde reagent, which produced spots of different shades of pink and violet. These spots were also observed with standard $\mathrm{H}_{2} \mathrm{SO}_{4}$, antimony chloride reagent, and $0.2 \%$ $\mathrm{KMNO}_{4}$.

The phenolic fraction was identified after acid hydrolysis of the dried ground plant extract. Acid hydrolysis was done with $2 \mathrm{M} \mathrm{HCl}$ for $30 \mathrm{~min}$. The product workup created an organic fraction that was analyzed by TLC. After separation on silica gel using $45 \%$ ethyl acetate in hexane, blue spots were detected with Folin's reagent.

The main constituents of $C$. brasiliense are flavonoids and terpenoids. These chemical compounds have been identified as being antimicrobial agents [22-25] and contribute to the antioxidant activity demonstrated in our previous study [18].

Flavonoids can interact with the cytoplasmic membrane, inhibiting its function and jeopardizing cellular integrity. They can also inhibit the synthesis of nucleic acids and interrupt bacterial metabolism [26].

Terpenoids are, in general, recognized as being safe. They have been found to inhibit the growth of cancerous cells as well as decrease tumor size, serum cholesterol levels, and microorganism concentrations [27,28]. Terpenoids have lipophilic characteristics that affect the stability of the cytoplasmic membrane, leading to loss of cellular enzymes and nutrients [29].

Of particular interest, the phytochemical groups, flavonoids and terpenoids, present in CBSE are associated with a range of anti-inflammatory, antimicrobial, antiedematogenic, and antioxidant activities [30].

\section{Cytotoxicity and phototoxicity potential}

The cytotoxic potential of CBSE was evaluated by the XTT assay in murine fibroblasts (3 T3) incubated with the extract (0.0001-50.00\%). The extract exhibited negligible cytotoxicity, because its $\mathrm{IC}_{50}$ is $>50.0 \%$ and none of the test concentrations could reduce cell viability to $50 \%$ (Figure 1). None of the test concentrations showed a decrease in cell viability compared with the control group $(\mathrm{p}<0.05)$.

Figure 2 presents the $\mathrm{IC}_{50}$ values for CBSE predicted by linear interpolation in the phototoxicity assay considering dark $(6.50 \% \mathrm{w} / \mathrm{v})$ and irradiated $(35.53 \% \mathrm{w} / \mathrm{v})$ conditions. According to analyses of the PIF and MPE, CBSE did not exhibit phototoxic potential (PIF $=0.18$ and $\mathrm{MPE}=-0.062$ ) in the dose levels tested.

Cytotoxicity was assessed in fibroblast cultures with direct contact between CBSE and basal cells. This is a drastic situation compared with regular use of cosmetics, in which the initial contact occurs in the stratum corneum, a keratinized tissue for skin protection [31].

In general, in vitro safety tests are based on disruption of membrane integrity as determined by pigment absorption, to which the cell is (in general) impermeable, or the retention of released pigment by viable cells [32]. Among bioassays, cell toxicity tests are the first to be carried out to predict the toxicity of substances to various tissues [33].

Tests of cell viability provide information about short or immediate responses, thereby enabling determination of the proportion of viable cells after a traumatic procedure. Although in vitro tests used to evaluate toxicity 


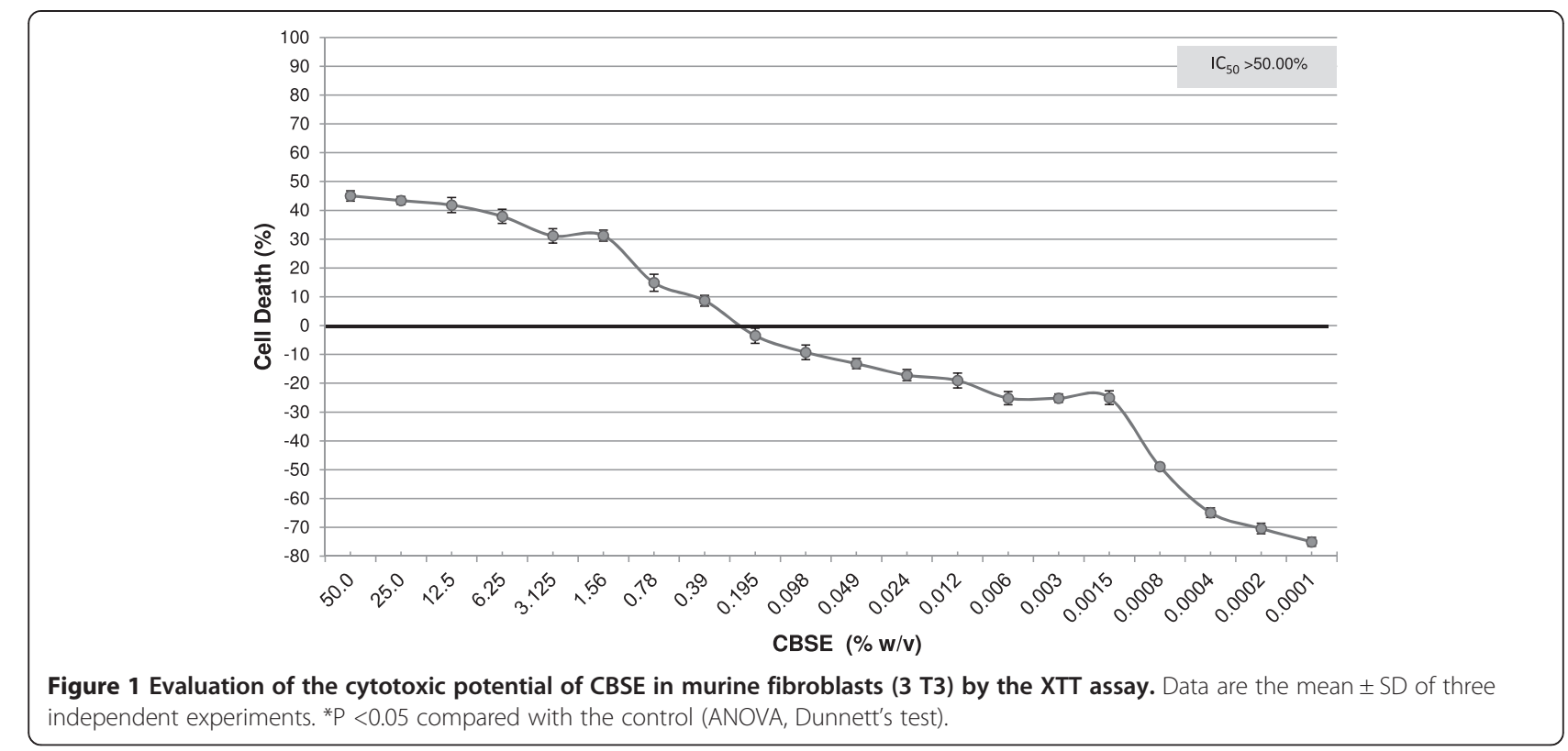

cannot completely replace in vivo tests, they provide useful information regarding the factors that influence growth and cell survival [34].

Alternatives to animal testing and the identification of validated methods that may decrease the need for animals are currently the subject of intense investigation worldwide. The in vitro tests provide an alternative means for the assessment of natural and synthetic ingredients with time efficiency, and cost effectiveness [35].

C. brasiliense (Pequi) is used topically for wound dressings [11] and has the potential for skin hydration and barrier maintenance, as well as the hydrolipidic mantle [17]. The relatively few studies focusing on screening of the phototoxic activity of plant extracts employed as cosmetics led us to investigate the effect of CBSE. Studies investigating the cytotoxicity or phototoxicity of CBSE are lacking but Roesler et al. [7] showed that the ethanolic extracts of pequi peel and seed were not phototoxic (PIF <5).

In vitro cytotoxicity results are used to screen toxicity and to estimate the $\mathrm{IC}_{50}$ of chemicals. The NRU phototoxicity assay using $3 \mathrm{~T} 3$ cells has been validated by the European Union Reference Laboratory for Alternatives to Animal Testing, and accepted for regulatory use to detect the phototoxic potential of substances. Phototoxic potential is assessed by comparing the differences in

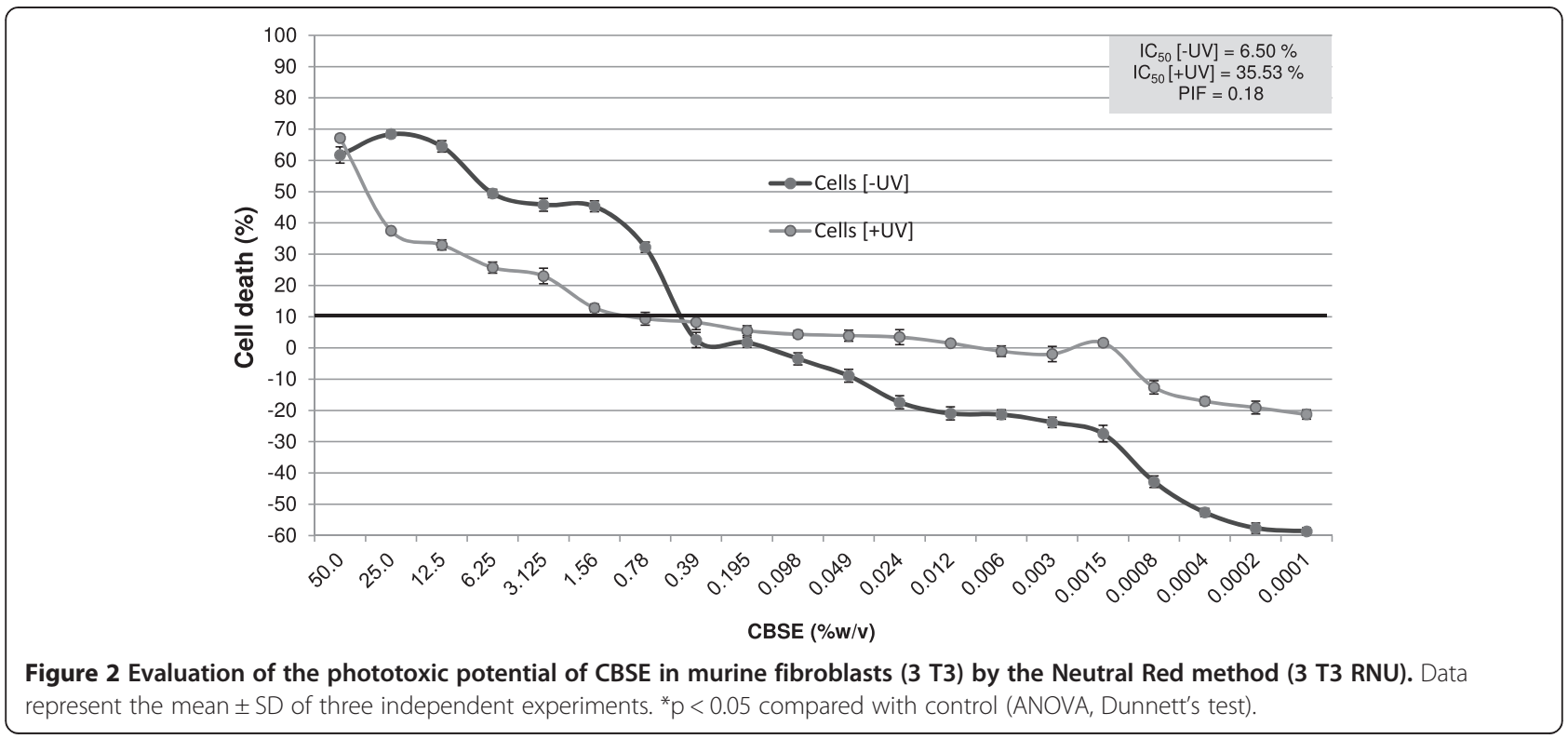


toxicity between negative control plates not exposed to UVA and test plates exposed to UVA [7].

As demonstrated by several validation studies, the phototoxic potential of chemicals can be evaluated effectively by in vitro methods [36]. However, the neutral red assay (3 T3 NRU) is a validated method for the replacement of tests involving animals [37].

The phototoxicity results obtained by the in vitro NRU method are of great importance (especially for cosmetic and pharmaceutical application) because topical formulations are commonly used during the day and involve exposure to the sun and artificial light.

There is a wide search for dermatological actives derived from plants (e.g., fragrance, antimicrobials, antioxidants). However, these plants used in traditional "folk" medicine are associated with cytotoxicity and phototoxicity. In view of this observation, evaluation of the cytotoxic and phototoxic potential of extracts or vegetal actives becomes essential for the development of products for dermatological use [38-42].

We sought to provide information about the biological behavior of CBSE to propose its cosmetic and/or pharmaceutical use. Some researches shown that oils and extracts normally comprising a mixture of components, have better therapeutic activity than the known compounds that represent their main composition. An example of such statement is the antiseptic activity of the essential oil of Eucalyptus globulus, higher than the activity shown by its main active constituent isolated, cineol or eucalyptol [43].

In some situations, the results of the tests that evaluate in vitro safety might not be related directly to the results obtained through in vivo tests. However, a material that induces a reaction in tests involving cell cultures is likely to demonstrate toxic potential if applied to living tissues [44].

Our results are also a screening procedure to assess toxicity. Also, as one of the factors used to estimate the starting dose for in vivo acute lethality studies, this approach could reduce the number of animals used in in vivo studies and minimize the number of animals that receive lethal doses.

The safety of Caryocar brasiliense supercritical extract has not been well reported at scientific literature and the lack of reliable data does not allows a good comparison of our results. Thus, additional researches are needed to explore other toxicity pathways of this species that has a great potential of use in cosmetic and/or pharmaceutical products.

\section{Conclusions}

Under the test conditions described, C. brasiliense (pequi) extract obtained by supercritical $\mathrm{CO}_{2}$ extraction did not appear to have cytotoxic and phototoxic hazards. This finding suggests that the extract may be useful for the development of cosmetic and/or pharmaceutical products.
However, more detailed research is needed to explore other toxicity pathways.

\section{Competing interests}

The authors declare that they have no competing interests. There is no financial relationship with other people or organizations in implementation, analysis or financing of this study.

\section{Authors' contributions}

LFBA carried out the in vitro safety experiments and wrote the paper. All authors evaluated the data, read, reviewed and approved the final manuscript.

\section{Acknowledgements}

The authors thank the company Chemyunion Química Ltda. for their cooperation in obtaining the extracts and for allowing the use of its laboratories. The authors are also grateful to FAPESP for the financial support.

\section{Author details}

${ }^{1}$ Department of Clinical Pathology, Faculty of Medical Sciences, University of Campinas (FCM-UNICAMP), Rua Tessália Vieira de Camargo, 126 Campinas, SP, Brasil. ${ }^{2} \mathrm{CPQBA}$ - Multidisciplinary Center of Chemical, Biological and Agricultural Researches, University of Campinas (UNICAMP), Rua Alexandre Cazellato, 999, Vila Betel, Paulínia, SP, Brasil.

Received: 28 June 2014 Accepted: 7 October 2014 Published: 18 November 2014

\section{References}

1. Matias EFF, Santos KKA, Costa JGM, Coutinho HDM: Screening for in vitro phototoxic activity of methanol extracts of Croton campestris. Indian J Med Res 2010, 132(5):520-522.

2. Bulus T, Atawodi SE, Mamman M: Acute toxicity effect of the aqueous extract of Terminalia avicennioides on white albino rats. Science World J 2011, 6(2):1-4.

3. Nguta JM, Mbaria JM, Gakuya DW, Gathumbi PK, Kabasa JD, Kiama SG: Evaluation of acute toxicity of crude plant extracts from kenyan biodiversity using brine shrimp, Artemia salina L. (Artemiidae). Open Conference Proc J 2012, 3:30-34

4. Spielmann H, Balls M, Dupuis J, Pape WJ, Pechovitch G, de Silva O, Holzhütter HG, Clothier R, Desolle P, Gerberick F, Liebsch M, Lovell WW, Maurer T, Pfannenbecker U, Potthast JM, Csato M, Sladowski D, Steiling W, Brantom P: The international EU/COLIPA in vitro phototoxicity validation study: results of phase II (blind trial). Part 1: the 3 T3 NRUphototoxicity test. Toxicol Vitro 1998, 12(3):305-327.

5. Ekwall B: Screening of toxic compounds in mammalian cell cultures. Ann N Y Acad Sci 1983, 407:64-77.

6. Grisham JW, Smith GJ: Predictive and mechanistic evaluation to toxic responses in mammalian cell culture systems. Pharmacol Rev 1984, 36(2):151S-171S

7. Roesler R, Lorencini M, Pastore G: Brazilian cerrado antioxidant sources: cytotoxicity and phototoxicity in vitro. Cienc Tecnol Aliment 2010, 30(3):814-821.

8. Franquilino E: Ativos amazônicos. Cosmet Toiletries 2006, 18(5):18-24.

9. Almeida SP, Silva JA: Piqui E Buriti: Importância Alimentar Para A População Dos Cerrados. Planaltina: EMBRAPA-CPAC; 1994.

10. Vera R, Eli RB, Eliana PF, Ronaldo VN, Manoel SSJ, Márcio C, Paulo AX: Caracterização física e química de frutos do pequizeiro (Caryocar brasiliense Camb.) oriundos de duas regiões no estado de goiás, Brasil. Pesquisa Agropecuária Tropical 2007, 37(2):93-99.

11. Matos FJA: Plantas Medicinais: Guia De Seleção E Emprego De Plantas Usadas Em Fitoterapia No Nordeste Do Brasil. 3rd edition. Fortaleza: Imprensa Universitária; 2007.

12. Lima FN: Plantas Medicinais Comercializadas Nos Municípios de Crato, Juazeiro do Norte e Barbalha-CE. Crato: Universidade Regional do Cariri; 1996.

13. Londe LN, Vieira CU, Kerr WE, Bonetti AM: Characterization of DNA polymorphisms in Caryocar brasiliense (Camb.) in populations with and without thorn at the endocarp by RAPD markers. Ann Braz Acad Sci 2010, 82(3):779-789 
14. Oliveira IG, Cartaxo SL, Silva MAP: Plantas medicinais utilizadas na farmacopéia popular em Crato, Juazeiro e Barbalha (Ceará, Brasil). Revista Brasileira de Biociências 2007, 5(1):189-191.

15. Santos BR, Paiva R, Dombroski JLD: Pequizeiro (Caryocar brasiliense Camb.): uma espécie promissora do cerrado brasileiro. 64th edition. Boletim Agropecuário da Universidade Federal de Lavras; 2004. Available at < http://editora.ufla.br/upload/boletim/tecnico/boletim-tecnico-64. pdf $>$. Accessed on May 10, 2014

16. Facioli NL, Gonçalves LAG: Modificação por via enzimática da composição triglicerídica do óleo de piqui (Caryocar brasiliense Camb.). Quim Nova 1998, 21(1):16-19.

17. Rieger MM: Skin lipids and their importance to cosmetic science. Cosmet Toiletries 1997, 102(7):45-49.

18. Amaral LFB, Moriel P, Foglio MA, Mazzola PG: Caryocar brasiliense supercritical $\mathrm{CO}_{2}$ extract possesses antimicrobial and antioxidant properties useful for personal care products. BMC Complement Altern Med 2014, 14:73.

19. Harborne JB: Phytochemical Methods: A Guide To Modern Techniques Of Plant Analysis. 3rd edition. London, UK: Chapman \& Hall; 1998.

20. Holzhütter HG: A general measure of in vitro phototoxicity derived from pairs of dose-response curves and its use for predicting the in vivo phototoxicity of chemicals. ATLA 1997, 25:445-462.

21. Liebsch M, Spielmann H: INVITTOX Protocol No. 78: 3 T3 NRU Phototoxicity Assay. EURL ECVAM DB-ALM: Protocols. 1998. Last update December 2008. Available at <. http://ihcp.jrc.ec.europa.eu/our_labs/eurl-ecvam/validationregulatory-acceptance/doc-phototox/INVITTOX-DB-ALM-78.pdf >. Acessed on May 10, 2014.

22. Paula-Júnior W, Rocha FH, Donatti L: Leishmanicidal, antibacterial, and antioxidant activities of Caryocar brasiliense Cambess leaves hydroethanolic extract. Rev bras Farmacogn 2006, 14:625-630.

23. Bezerra JC, Silva IA, Ferreira HD, Ferri PH, Santos SC: Molluscicidal activity against Biomphalaria glabrata of Brazilian Cerrado medicinal plants. Rev Fitoterapia 2002, 73(5):428-430.

24. Barreto GP, Benassi MT, Mercadante AZ: Bioactive compounds from several tropical fruits and correlation by multivariate analysis to free radical scavenger activity. J Braz Chem Soc 2009, 20(10):1856-1861.

25. Harborne JB, Baxter H: The Handbook of Natural Flavonoids. 1 and 2nd edition. Chichester, UK: John Wiley and Sons; 1999.

26. Cushnie TPT, Lamb AJ: Antimicrobial activity of flavonoids. I Inter J Antimic Age 2005, 26:343-356.

27. Kumar A, Samarth RM, Yasmeen S, Sharma A, Sugahara T, Terado T, Kimura $\mathrm{H}$ : Anticancer and radioprotective potentials of Mentha piperita. Biofactors 2004, 22:87-91.

28. Gupta N, Saxena G, Kalra SS: Antimicrobial activity pattern of certain terpenoids. Int J Pharmacol Bio Sci 2011, 2:87-91.

29. Cox SD, Mann CM, Markham JL, Bell HC, Gustafson JE, Warmington JR, Wyllie SG: The mode of antimicrobial action of the essential oil of Melaleuca alternifolia (tea tree oil). J Appl Microbiol 2000, 88:170-175.

30. Eberlin S, Pereda MDCV, Dieamant GC, Nogueira C, Werka MV, Queiroz MLS: Effects of a Brazilian herbal compound as a cosmetic eyecare for periorbital hyperchromia ("dark circles"). J Cosmet Dermatol 2009, 8:127-135.

31. Skowroñ J, Zapór L: Cytotoxicity of resorcinol under short- and long-term exposure in vitro. Int J Occup Saf Ergon 2004, 10(2):147-156.

32. Freshney Rl: Culture of Animal Cells: A Manual of Basic Technique. 5th edition. New York: Wiley-Liss; 2005:642.

33. Silva TMA, Aoyama H, Haun M, Ferreira CV: Citotoxicidade do promotor de tumor e sua ação mitogênica sobre os linfócitos humanos. Rev Bras Anal Clin 2004, 36(4):237-239.

34. National Institute of Health - NIH: Evaluation of In Vitro Cytotoxicity Test Methods: Guidance document on using in vitro data to estimate in vivo starting doses for acute toxicity, NIH Publication No. 01-4500; 2001

35. Agência Nacional de Vigilância Sanitária - ANVISA: Guia para Avaliação de Segurança de Produtos Cosméticos. 2nd edition. Brasília: Anvisa; 2012.

36. Borenfreund $E$, Puerner JA: Toxicity determined in vitro by morphological alterations and neutral red absorption. Toxicol Lett 1985, 24(2-3):119-124.

37. Peters B, Holzhütter HG: In vitro phototoxicity testing: development and validation of a new concentration response analysis software and biostatistical analyses related to the use of various prediction models. Altern Lab Anim 2002, 30(4):415-432.

38. Groot AC, Bruynzeel DP, Bos JD, Van Der Meeren LM, Van Joost T, Jagtman BA, Weyland JW: The allergens in cosmetics. Arch Dermatol 1988, 124:1525-1529.
39. Jackson EM: Substantiating the safety of fragrances and fragranced products. Cosmet Toilet 1993, 108(6):43-46.

40. Soni MG, Burdock GA, Taylor SL, Greenberg NA: Safety assessment of propyl paraben: a review of the published literature. Food Chem Toxicol 2001, 39:513-532.

41. Soni MG, Taylor SL, Greenberg NA, Burdock GA: Evaluation of the health aspects of methyl paraben: a review of the published literature. Food Chem Toxicol 2002, 40:1335-1373.

42. Soni MG, Carabin IG, Burdock GA: Safety assessment of esters of p-hydroxybenzoic acid (parabens). Food Chem Toxicol 2005, 43:985-1015.

43. Simões CMO, Schenkel EP, Gosmann G, Mello JCP, Mentz LAA, Petrovick PR: Farmacognosia: da planta ao medicamento. 5th edition. Florianópolis: UFSC; 2000.

44. Osorio RM, Hefti A, Vertucci FJ, Shawley AL: Cytotoxicity of endodontic materials. J Endod 1998, 24:91-96.

doi:10.1186/1472-6882-14-450

Cite this article as: Amaral et al:: Evaluation of the cytotoxicity and phototoxicity of Caryocar brasiliense supercritical carbon dioxide extract. BMC Complementary and Alternative Medicine 2014 14:450.

\section{Submit your next manuscript to BioMed Central and take full advantage of:}

- Convenient online submission

- Thorough peer review

- No space constraints or color figure charges

- Immediate publication on acceptance

- Inclusion in PubMed, CAS, Scopus and Google Scholar

- Research which is freely available for redistribution

Submit your manuscript at www.biomedcentral.com/submit
C) Biomed Central 